\title{
STUDENT CAREER PREPARATION IN THE REGIONAL ECONOMIC INTEGRATION - ASEAN ECONOMIC COMMUNITY
}

\author{
LE HONG YEN NHI \\ International University - Vietnam National University HCMC, Vietnam - nhilehongyen@ gmail.com \\ NGUYEN THI QUYNH NHI \\ International University - Vietnam National University HCMC, Vietnam - nhinguyen9594@gmail.com
}

NGUYEN VAN PHUONG

International University - Vietnam National University HCMC, Vietnam - nvphuong@ hcmiu.edu.vn

NGUYEN THI HONG AN

International University - Vietnam National University HCMC, Vietnam - nthan@ hcmiu.edu.vn

(Received: November 22, 2016; Revised: December 02, 2016; Accepted: April 10, 2017)

\begin{abstract}
Globalization and regionalization have influenced Vietnam labor market more robustly, especially since the establishment of the ASEAN Economic Community in 2015. Hence, preparing for students for a dynamic workforce becomes critical. This paper examines the attributes of student career preparation and their relationships with the willingness to work in ASEAN. We used the Structural Equation Model to test the research model with the data collection of 317 university students in Ho Chi Minh City, Vietnam. The empirical result indicated that regional economic integration awareness and academic experiences have remarkably influenced on career preparation, which also had strong impact on the willingness of students to accept working overseas. Moreover, the students' willingness to accept international job was affected by awareness of linguistic skills influence and cultural awareness. Specifically, Vietnamese students have been reluctant to working in ASEAN after graduation despite the influence of globalization and regionalization. Besides, we also conducted 10 in-depth interviews to highlight our quantitative results and achieve further understanding of the hidden causes. Thus, the paper discussed critical recommendations to improve student career preparation and confidence.
\end{abstract}

Keywords: Career preparation; Regional economic integration; work overseas; linguistic skills; cultural.

\section{Introduction}

Career preparation has been considered as a primarily advancing task for students, the careful and successful process of which will enhance the chances of personal maturity, social balance, and future prosperity (Erikson, 1968; Super, 1990). Although it is essential to prepare youth for a knowledge-based economy and globalization, career education and vocational psychology has been ignored in study curriculum and teaching programs (Fredricks et al., 2004). This issue has become more and more urgent and important since globalism, multiculturalism and speedy updating technology request a distinctively skilled and more knowledgeable workforce and promote life-long learners.

In Vietnam, more than 70 percent of students have not adequately prepared and taken any steps to capture opportunities for the job market after graduating (Trinh and Pham, 2013). Tran (2014) reported that 70\% students are not well prepared for their future career, especially referring to soft skills and English competence. Ministry of Labor, War Invalids and Social Affairs (2015) announced that unemployment rate of Vietnamese young labor (15-24 years old) was 586.2 thousand people nationwide in the first quarter of 2015 , which makes up $50.5 \%$ total unemployment quantity. Furthermore, when entering the workforce, $13 \%$ graduates had to be retrained 
or attend additional training programs, $40 \%$ needed to be carefully supervised in working process, and $41 \%$ required long time to be familiar with the tasks (Ministry of Labor, War Invalids and Social Affairs, 2015). Hence, preparation for future career has required immediate attention for not only the students but also the education administrators.

Although a number of studies have addressed concepts and relevant models concerning career preparation, few empirical studies have developed an integrative model capable to examine the occupational awareness in the context of relationships between regional economic integration, willingness to work in integration region, support of enhancement partners. Recently, researchers also have recognized that there is a growing need to conduct longitudinal studies, which would address the issues of continuity in student career development process in the relationships between career preparation and adjustment (Creed, Prideaux, \& Patton, 2005; Jepsen \& Dickson, 2003; Vondracek \& Skorikov, 1997).

Consequently, given the fact that there is limited empirical research on career preparation, this study developed a conceptual framework to test career preparation model and its relevant components in the context of economic integration, so that the results can help students and educational counselors to build comprehensive strategies, which aim to orientate and guide students for their future career. This paper aims to develop a model of career preparation under the regional economic integration and introduce recommendations to boost the preparation for career path of students by educators and career counselors.

\section{Literature review}

\subsection{Career preparation}

Careers have been observed as "a sequence of positions occupied by a person during the course of a lifetime" (Super, 1957), "the development of vocational behavior over time" (Savickas, 2002), or "a sequence of work experiences over time - unfolded"
(Arthur \& Rousseau, 2001). According to Parsons (1909), the most essential phrase in life that requires navigation is school-to-work transition as it is quite speculative for students to jump into the real and complex world then fail or succeed. Therefore, career development guidance or career preparation should be prioritized and significantly critical for educators and school counselors to equip students for their future jobs. (Hughey, 1999).

Career preparation is considered as a crucial part of the education of higher-level students, which means assisting adolescents to develop important career decision-making skills (Marock, 2008), such as self-awareness of personal interests, values, and aspirations, career planning, goal-setting skills, and job search skills (Zunker, 2006). Due to career preparation assistance, adolescents can have the ability to recognize a career identity, explore personal skills and interests, collect information about different career paths and make critical decisions about the careers desired (Feldman, 2002; Zunker, 2006). However, while Medel (1994) only focused on explaining why students are not going to college, Hughey (1999) emphasizes that prioritizing career development activities is obligatory in the educational program regardless of educational levels. The indicators of career preparation include career planning, career decision making, selfefficacy, vocational identity, and career expectations (Skorikov, 2007). Among the components of career preparation, although negligence of psychological orientation and career expectations can cause much anxiety and depression (Hellenga, Aber, \& Rhodes, 2002), research on adolescents' career planning and decision-making was limited or resulted ambiguous. In this study, career preparation is measured by two constructs: career planning and career decision-making (Loutfallah, 2014).

Career planning is defined as "a futureoriented attitudinal and behavioral approach to one's projected or envisioned career pathway" (Perry, 2010). There have been a number of 
various theories about career decision-making. Social theories suggest that career is constrained by availability of current labor market rather than individual's choice (Robert, 1968) and career decision-making is influenced by others' role in affecting career preferences. One of the most common theories is Social Cognitive Career Theories, which introduce that career development process is induced by self-efficacy expectation and result confidence (Lent et al, 1994). However, it seems that the instruments have not been strongly appropriate to career in the dynamic workplace today (Leung, 2008). In the meanwhile, career decision-making has been investigated by the framework of Person-Environment Fit theories. The pioneer, Parsons (1909) implied that there exists the possibility that one individual can match an occupation. This led to the debut of various questionnaires and tests to analyze the level of fit of one person to a job or occupation given job description, requirement, and skills. Among them, the most popular might be RIASEC (Realistic, Investigative, Artistic, Social, Enterprising \& Conventional) model to differentiate personalities and interest, then recommended the proper profession (Holland, 1997).

It has become more reasonable when students have been facing the challenges of being competitive in the workforce due to continuous changes in the workplace (Feller, 1996). The workplace has been shifting from traditional triangle-shaped to emerging diamond-shaped. Specifically, traditional workplace is centralized control, mass production concentrating on individual tasks while decentralized control and team work are the keys of new workplace (Feller, 1996). Therefore, effective workers need interpersonal skills and accomplishment in managing and using resources, information, systems, and technology (SCANS, 1991).

New career-thinking supporters proposed that the socio-cultural and economic elements controlled by the current business contexts are the key impacts shaping careers (Arthur \& Rousseau, 1996; Miles \& Snow, 1996).
Moreover, there have been theorists investigated the influence on individual's career choice by external factors, including changing economy, the changing world of work, local market conditions (Hansen, 1997; Johnson \& Mortimer, 2002). However, a consolidated theoretical framework for practitioners is missed and the scope is bounded to variables of main concern by sociologists (Duffy \&Dik, 2009). Besides, influence of globalization on careers is inevitable, which leads to a more internationally competitive workforce (Hughey, 1999). Research by Newburry et al (2008) suggested that globalization had been brought along with employees' perception of preferable career opportunities. Therefore, all kinds of jobs are impacted strongly by international trade, multinational corporations, and technological interdependencies (Tams \& Arthur, 2007). Nonetheless, in their study, the link between careers some sources of global interdependence containing free trade, labor flow, economic and political integration such as NAFTA, European Union, ASEAN, etc. requires further exploration, along with different participations of international institutions, financial banks, nongovernmental organizations.

To better career preparation, academic experience is viewed as a considerable factor as it measures students' expectation and perception of their academic ability (Fisher \& Stafford, 1999). While other studies examine the relationship between specific subjects and career development, it is suggested that general academic experience would be more profitable to investigate. Trice and Yoo (2007) found that there was a close relationship between academic experience and students' career plan after graduation. In this model, regional economic integration awareness and academic experience are two key impacts on career preparation as follows:

$\mathrm{H} 1$ : Regional economic integration awareness will positively affect career preparation.

$\mathrm{H} 2$ : Academic experiences will positively 
influence career preparation.

\subsection{Willingness to work in ASEAN}

Willingness to work overseas is viewed as having motivation and eagerness to get involved in a job market, an assignment across nations or migration to a foreign country in the short term or long term. Noe and Barber (1993) presented significant evidence that employee's willingness to accept mobility depends on their satisfactory of career preparation. In other words, a student who is well-prepared about career development and engaged in an advanced vocational program can welcome international job opportunities. This was also mentioned in Granrose and Portwood's study (1987) that the better career preparation ones receive to have more job opportunities in the future, the more willing to mobile they are to seek jobs. An economic integration is expected to boost willingness to work overseas as well. For example, an empirical study found that the establishment of European Union, which created the Single European Market, encouraged mobility of labor (Thom, 1992). Integration can alter limits and motivation for labor migration (Ottaviano \& Thisse, 2002), which can increase willingness to work across regions (Zimmermann, 2005). In this research, working in ASEAN is the main focus. Therefore, the following hypotheses are proposed:

H3: Career preparation will positively influence willingness to work in ASEAN.

H4: Regional economic integration awareness will positively influence willingness to work in ASEAN.

This global economic integration urges the forthcoming participants for linguistic and cultural awareness, which might be gained as part of their education (Tremblay, 2002). Fraser (1991) also indicated that failure was highly possible when professionals depreciate between cultural and linguistic disparity in foreign working environment. Therefore, professionals' prosperity reckons on the adjustability of cultural and linguistic variation in international assignments (Forster, 1992). On the other hand, policy maker's nations facing integration would try to introduce and protect national identity. In the European Union adaptation, France adopted immigration policy that encourages people who enjoy French language and culture (Zimmermann, 2005). There, we developed two hypotheses:

H5: Awareness of linguistic skills influence will positively influence willingness to work in ASEAN.

H6: Cultural awareness will positively influence willingness to work in ASEAN.

In general, this study aims to explain the forces of economic integration to career preparation of students and their willingness to work in ASEAN by testing model associating with academic experience, awareness of linguistic skills influence, and cultural awareness. Regional economic integration in this study means the context of ASEAN Economic Community establishment in 2015. Figure 1 illustrates our conceptual framework with proposed hypotheses.

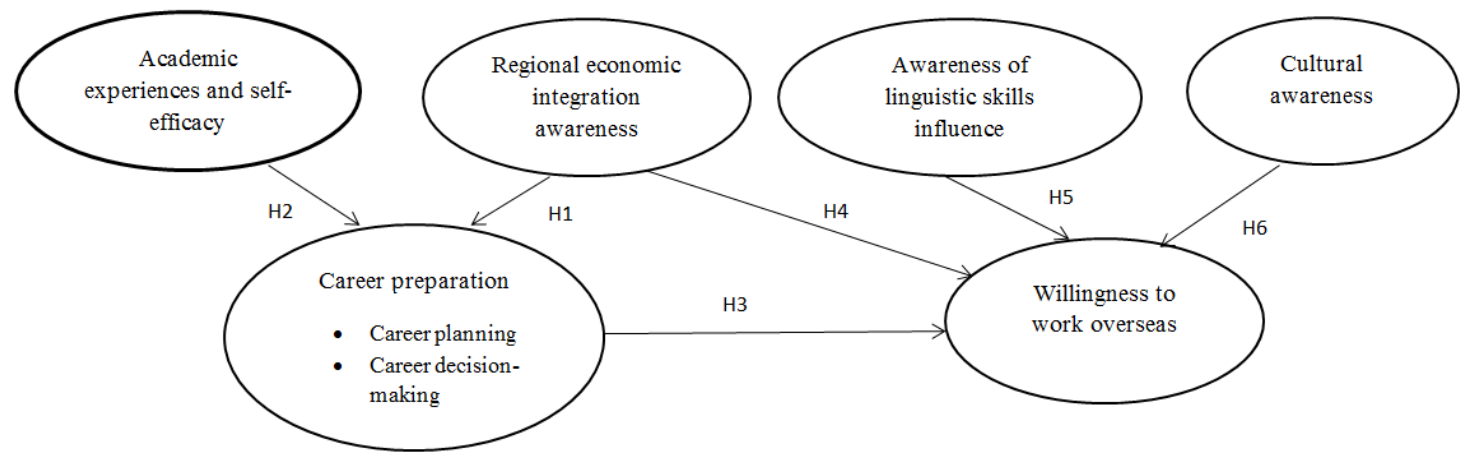

Figure 1. Conceptual framework 


\section{Methodology}

This research uses the quantitative method to test the research framework and implements 10 in-depth interviews to highlight the research results and discovery the latent motivation. The structure of the questionnaire contains two parts with the total of 39 items. The first one asks respondents about demographic background, including gender, college classification, university attending, and AEC awareness.
The second analyzes students' career preparation and work mobility willingness on four primary factors referring to regional economic integration, academic experiences, awareness of linguistic skills influence, and cultural awareness. The career preparation is measured by two second-order factors labeled Career planning and Decision making. The questionnaire is adapted and modified from the reliability scale in previous studies.

\section{Table 1}

Measurement scale

\begin{tabular}{|c|c|c|c|}
\hline Factor & Code & Meaning & References \\
\hline \multirow{6}{*}{ Career planning } & $\mathrm{CP} 1$ & Parental discuss toward education plans & \multirow{6}{*}{$\begin{array}{l}\text { Loutfallah, S. W. } \\
(2014)\end{array}$} \\
\hline & $\mathrm{CP} 2$ & Market trends influence & \\
\hline & $\mathrm{CP} 3$ & Outside materials and information & \\
\hline & $\mathrm{CP} 4$ & Changing because of failure & \\
\hline & CP5 & Goal setting support & \\
\hline & CP6 & Five-year planning & \\
\hline \multirow{6}{*}{$\begin{array}{l}\text { Career decision- } \\
\text { making and self- } \\
\text { efficacy }\end{array}$} & DM1 & Possible career list & \multirow{6}{*}{$\begin{array}{l}\text { Loutfallah, S. W. } \\
(2014)\end{array}$} \\
\hline & DM2 & $\begin{array}{l}\text { Determination level in case of advisor } \\
\text { objection }\end{array}$ & \\
\hline & DM3 & Professional interest match & \\
\hline & DM4 & Value of freedom in career choice & \\
\hline & DM5 & Self-responsibility & \\
\hline & DM6 & Internship & \\
\hline \multirow{4}{*}{$\begin{array}{l}\text { Cultural } \\
\text { awareness }\end{array}$} & CK1 & Foreign culture interest & \multirow{4}{*}{$\begin{array}{l}\text { Kitsantas, A. } \\
\text { (2004). }\end{array}$} \\
\hline & CK2 & Foreign language & \\
\hline & CK3 & Culture learning opportunities & \\
\hline & CK4 & Foreign understanding & \\
\hline \multirow{3}{*}{$\begin{array}{lr}\text { Awareness } & \text { of } \\
\text { Linguistic } & \text { skill } \\
\text { influence } & \end{array}$} & LK1 & Employment differences in skill application & \multirow{3}{*}{$\begin{array}{l}\text { Ely, C. M. } \\
(1986)\end{array}$} \\
\hline & LK2 & University advantage & \\
\hline & LK3 & Skills application & \\
\hline
\end{tabular}




\begin{tabular}{|c|c|c|c|}
\hline Factor & Code & Meaning & References \\
\hline & LK4 & English application & \\
\hline \multirow{5}{*}{$\begin{array}{l}\text { Academic } \\
\text { experiences }\end{array}$} & AE1 & Grade & \multirow{5}{*}{ Perry et al (2010) } \\
\hline & AE2 & Confidence at ability & \\
\hline & AE3 & Study strategies & \\
\hline & AE4 & Personal strengths & \\
\hline & AE5 & Subject identification & \\
\hline \multirow{7}{*}{$\begin{array}{l}\text { Regional } \\
\text { economic } \\
\text { integration } \\
\text { awareness }\end{array}$} & RI1 & Integration influence on job opportunities & \multirow{7}{*}{$\begin{array}{l}\text { Newburry, W., } \\
\text { Belkin, } \\
\text { L. Y., \& Ansari, P. } \\
(2008)\end{array}$} \\
\hline & RI2 & International career opportunities & \\
\hline & RI3 & Business travel & \\
\hline & RI4 & Global clients & \\
\hline & RI5 & Culture approach & \\
\hline & RI6 & Global member consideration & \\
\hline & RI7 & Foreign projects & \\
\hline \multirow{7}{*}{$\begin{array}{l}\text { Willingness to } \\
\text { work in ASEAN }\end{array}$} & WO1 & Overseas job search & \multirow{7}{*}{$\begin{array}{l}\text { Noe, R. A., } \\
\text { \& Barber, A. E. } \\
(1993)\end{array}$} \\
\hline & WO2 & Language interaction & \\
\hline & WO3 & Mobility willingness & \\
\hline & WO4 & Confidence to overcome obstacles & \\
\hline & WO5 & International assignment & \\
\hline & WO6 & Oversea visiting & \\
\hline & WO7 & Foreign job information & \\
\hline
\end{tabular}

Likert 5-point rating scale is chosen, which allows showing the level agreement of respondents about a statement and indicating how strongly they perceive positively or negatively about these statements from "strongly disagree" to "strongly agree". A 50-case-pilot-study result was used to adjust and modify the final questionnaire so that it can satisfy time-saving and efficiency. From November 2015 to January 2016, there were 323 webbased and paper forms filled by respondents. However, only 317 valid observations were used in this study since six observations were omitted due to missing information, unconsciousness and lack of seriousness of the answers. The demographic information is illustrated as following: 


\section{Table 2}

Sample profiles

\begin{tabular}{|c|c|c|}
\hline Demographics & Frequency & Percent of sample (\%) \\
\hline \multicolumn{3}{|l|}{ Gender } \\
\hline Male & 170 & 53.63 \\
\hline Female & 147 & 46.37 \\
\hline \multicolumn{3}{|l|}{ School year } \\
\hline Freshman & 76 & 23.97 \\
\hline Sophomore & 84 & 26.50 \\
\hline Junior student & 68 & 21.45 \\
\hline Senior student & 89 & 28.08 \\
\hline \multicolumn{3}{|l|}{ University attending } \\
\hline International University (IU) & 87 & 27.44 \\
\hline Foreign Trade University (FTU) & 78 & 24.61 \\
\hline University of Economics HCMC (UEH) & 84 & 26.50 \\
\hline Other Universities & 68 & 21.45 \\
\hline \multicolumn{3}{|l|}{ Awareness of AEC 2015} \\
\hline Aware of AEC & 292 & 92.11 \\
\hline Unaware of AEC & 25 & 7.89 \\
\hline
\end{tabular}

Most of the students surveyed have background in economics and business faculties. The students which are among good universities in Ho Chi Minh City were selected due to their dedicated and austere manner in survey completion. Nonetheless, about a quarter of the sample comes from many other universities without ranking consideration.

\section{Data analysis}

The step-by-step analysis (Hair et al., 2012; Peng and Lai, 2012) was applied and the structural equation modeling is used after the validity of data was confirmed. AMOS is the main tool to analyze data due to its appropriation to the research model. Overall, the acknowledgement of AEC is widespread, which can be implied from the majority of students $(92.11 \%)$ who obtain the news and auxiliary information of AEC via the Internet, books, televisions, newspapers and other media channels. However, there are still $7.89 \%$ students unaware of these current and important economic events.

\subsection{Convergent validity and reliability}

Another critical criterion needs to be checked is Average Variance Extracted (AVE) which demonstrates the convergent validity. Bagozzi \& Yi (1988) affirm that convergent and discriminant validity can assure the acceptance of the measurement model. Convergent validity can be approved if the beta 
coefficient of its reciprocal item is larger than 0.5 (Steenkamp \& Trijp, 1991). Additionally, construct reliability is measured by composite reliability (CR) which can be calculated by Excel tools. In most cases, it is commonly acceptable for CRs to be over 0.7. Nonetheless, the case that the composite reliability is only higher than 0.6 still satisfy the convergent validity of the construct (Fornell and Larcker, 1981). All criteria are satisfactory.

Table 3

Assessment of convergent validity and reliability

\begin{tabular}{|c|c|c|c|c|}
\hline Construct & $\begin{array}{c}\text { Range of } \\
\text { Standardized } \\
\text { Loadings }\end{array}$ & Cronbach's $\alpha$ & $\begin{array}{l}\text { Composite } \\
\text { Reliability }\end{array}$ & AVE \\
\hline \multirow{2}{*}{$\begin{array}{l}\text { Regional economic integration awareness } \\
\text { (RI) }\end{array}$} & $0.583-0.852$ & 0.869 & 0.867 & 0.523 \\
\hline & $0.610-0.780$ & 0.854 & 0.837 & 0.510 \\
\hline Willingness to work in ASEAN (WO) & & & 0.708 & 0.548 \\
\hline Career Preparation & $0.614-0.729$ & 0.788 & & \\
\hline Career Planning $(C P)$ & $0.550-0.806$ & 0.801 & & \\
\hline Career Decision Making (DM) & $0.585-0.736$ & 0.793 & 0.754 & 0.510 \\
\hline \multirow{2}{*}{$\begin{array}{l}\text { Academic Experiences and Self- } \\
\text { Efficacy(AE) }\end{array}$} & $0.568-0.755$ & 0.682 & .696 & 0.542 \\
\hline & $0.509-0.830$ & 0.711 & 0.689 & 0.541 \\
\hline $\begin{array}{l}\text { Awareness of Linguistic Skills Influence } \\
\text { (LS) }\end{array}$ & & & & \\
\hline Cultural Awareness (CA) & & & & \\
\hline
\end{tabular}

\subsection{Discriminant validity}

Discriminant validity of the construct also needs confirming by comparing the square root of AVE value of a factor, its correlation and other factors. The discriminant validity is certified when the extracted variance of each measurement item is superior to the square of correlation estimates, which reveal its correlation with others construct (Fornell \& Larcker, 1981). Hence, all of these relevant criteria in the analysis are justified, which indicates the strong evidence for validity and reliability of measurement items.

\section{Table 4}

Assessment of discriminant validity (square root of AVE on diagonal)

\begin{tabular}{|l|l|l|l|l|l|l|}
\hline & WO & RI & AE & CK & LS & CPR \\
\hline WO & $\mathbf{0 . 7 1 4}$ & & & & & \\
\hline RI & 0.331 & $\mathbf{0 . 7 2 3}$ & & & & \\
\hline AE & 0.330 & 0.256 & $\mathbf{0 . 7 1 4}$ & & & \\
\hline CK & 0.287 & 0.242 & 0.089 & $\mathbf{0 . 7 3 5}$ & & \\
\hline LS & 0.348 & 0.230 & 0.360 & 0.295 & $\mathbf{0 . 7 3 6}$ & \\
\hline CPR & 0.458 & 0.380 & 0.288 & 0.666 & 0.169 & $\mathbf{0 . 7 4 0}$ \\
\hline
\end{tabular}




\subsection{Structural equation modeling}

In this stage, Structural Equation Modeling is applied to test the hypotheses introduced in the model with the criteria used are identical to those of CFA analysis. The result indicates that model fit is still acceptable as following. $\chi^{2} / \mathrm{df}=1.842(<2)$, $\mathrm{CFI}=0.919(>0.90)$, GFI $=0.887(>0.80)$,
AGFI $=0.859(>0.8)$, and RMSEA $=0.052$ $(<0.08)$. As illustrated in the table, five hypotheses proposed are valid as having the p-value significance below 0.05 . Only one hypothesis that Regional economic integration awareness positively influences Willingness to work in ASEAN is rejected due to its high p-value 0.124 .

\section{Table 5}

Structural model results

\begin{tabular}{|l|c|c|}
\hline \multicolumn{1}{|c|}{ Hypotheses } & Coefficient & Remark \\
\hline $\begin{array}{l}\text { H1: Regional economic integration awareness will positively } \\
\text { affect career preparation }\end{array}$ & $0.334^{* * *}$ & Supported \\
\hline $\begin{array}{l}\text { H2: Academic experience will positively influence career } \\
\text { preparation }\end{array}$ & $0.237 * *$ & Supported \\
\hline $\begin{array}{l}\text { H3: Career preparation will positively influence Willingness to } \\
\text { work in ASEAN }\end{array}$ & $0.313 * * *$ & Supported \\
\hline $\begin{array}{l}\text { H4: Regional economic integration awareness will positively } \\
\text { influence Willingness to work in ASEAN }\end{array}$ & 0.113 & Not \\
\hline $\begin{array}{l}\text { H5: Awareness of linguistic skills influence will positively } \\
\text { influence Willingness to work in ASEAN }\end{array}$ & $0.239^{* *}$ & Supported \\
\hline $\begin{array}{l}\text { H6: Cultural awareness will positively influence Willingness to } \\
\text { work in ASEAN }\end{array}$ & $0.171^{*}$ & Supported \\
\hline
\end{tabular}

Note: $*$ denotes $p<0.05, * *$ denotes $p<0.01$, and $* * *$ denotes $p<0.001$

\section{Discussion}

\subsection{Quantitative result}

Table 4 illustrates that five out of six hypotheses are supported. The dependent variable Career Preparation was significantly described by the two constructs Career planning and Career decision-making with a high coefficient over 0.7 . It is proved that career preparation is influenced by regional economic integration awareness (Tams \& Arthur, 2007) and academic experiences and self-efficacy (Fisher \& Stafford, 1999). Specifically, regional economic integration awareness is the more powerful factor with coefficient 0.334. However, regional integration awareness, which was literally certified by Thom (1992) and Zimmermann (2005), is not confirmed to have an impact on
Willingness to work in ASEAN.

Awareness of linguistic skills influence and cultural awareness is supported to be two important factors of Willingness to work in integration region (Foster, 1992; Zimmermann, 2005). Career preparation, nonetheless, is the strongest determinant (Noe and Barber, 1993) to the plan and decision of international job by students. Generally, career preparation is highly critical for students in pursuing their future career prosperity, especially in the regionalization and globalization circumstance.

Further analyses were conducted to explore whether exists a relationship between linguistics skill or cultural awareness and career preparation. Cultural awareness, though few researches have been found on this 
relation, is revealed to positively impact on career preparation with $\mathrm{p}$-value $<0.001$ and coefficient 0.654 . The equivalent result was found in the study of Stambulova and Alfermann (2009). The model, however, rejects the correlation between awareness of linguistic skills influence and career preparation. This can be explained by the fact that student take learning foreign language for granted. Particularly, second language is mandatory for all students regardless of their major and desired job.

\subsection{Qualitative result}

With the purpose of having better understanding of Vietnamese students' thoughts about AEC and their career preparation, along with the reasons why Vietnamese students tend to resist moving to seek a job in ASEAN; we interviewed ten respondents from different majors and universities. They are two junior students and two sophomores from IU - VNU, two freshmen and two senior students from Foreign Trade University, and lastly two senior students from University of Economics-HCMC. They are all majored in economics, business management, international business, or marketing. Each interview lasted during 20 minutes on average while respondents were consulted individually.

In general, we found out that although students were worried about the higher competitiveness of the labor force when AEC was established, they are confident in selfability, linguistic skills, and job opportunities. They claim that Vietnamese students' English has been competent enough to join regional and global integration. Moreover, they believe that AEC is quite similar to the fact that a lot of multinational companies (MNCs) have come to invest in Vietnam in the recent decade.

On the other hand, the majority of students interviewed have no intention to work in ASEAN or other countries after graduation. Their reluctance originates from several reasons: foreign security concern, unknown living cost and working environment, family disagreement, discrimination, cultural differences, available MNCs in Vietnam, satisfaction with local companies, political and regional contrast, and climate disfavor.

During the interviews, we learn that parental influence plays an important role in career preparation of students. The students who have positive parental support will result in good academic achievement, which leads to favorable career preparation. They also welcome all opportunities to work abroad, especially in ASEAN. Conversely, if family controls the entire student's decisions, their academic outcome and self-efficacy cannot reach the highest satisfaction. Consequently, career preparation is poor and impulsive. This finding is comparable with Nota et al. (2007) and Mortier et al. (2002).

\section{Conclusion and Recommendations}

In conclusion, the purpose of this study was to debate that regional economic integration awareness and career preparation have a close and aggressive relationship. Hence, it is essential to conduct study to analyse how international environment and cultural diversity affecting career and how students react and response to these opportunities and challenges, and more vitally, how they can qualify themselves to survive and compete in such a context.

Human resources experts predict that AEC can have huge impact on labor force in ASEAN in soon; notwithstanding, this change has not been noticeable in Vietnam. This can be one of the reasons for the unconsciousness and ignorance of students in Ho Chi Minh City about the regional economic integration.

In addition, most of the students are confident and hopeful about their capabilities in the workplace. The statistics of high unemployment rate among fresh graduates do not support for the state that students are unable to work well in the workplace. In many of the cases, students always need a 
certain time after graduation to seek a suitable job and can switch among various positions and fields. In other words, protean career has been popular and common in young generation. On the other hand, students lacking skills, knowledge and making poor career decision is still the existing problem.

Successful career preparation for students demands the collaboration among students, teachers, school or career counselors, parents and the community. The activities that should be implemented can directly or indirectly involve students. Career development program should initiate from elementary schools and follow up in higher education levels to guide students about their career interest, career trends, realistic working environment, and suitable skills to pursue the desired career. In addition, students should be taught how to make a wise career decision and develop their action plan. There is a fact that some students are still ambiguous about their dreaming job and do not have a specific desire career or perhaps their interests belong to a category of many types of jobs. Therefore, career preparation can help them know the process of decision making and be competent and prepared for different choices that they are considering. This also helps students to adapt quickly and to be flexible when switching to another job or any other alteration in the world of work.

In the process of career preparation, selfexploration and self-assessment are extremely important and can be done through individual counseling by school or career counselors. According to a human resource expert we interviewed, parent is the first and key factor influencing the career choice and development since the students are at the very young age. Children lose the ability to make decision due to parents' criteria when they are taught to obey and follow all adults' sayings. This causes the dependence of students in the adolescent stage when they are not proactive and not dedicated to explore their passion and abilities. Therefore, students need the freedom and support in career choice and preparation.

Moreover, another expert in Human Resource Management suggested that more training programs should be implemented, specifically in each soft skill, and are arranged in an appropriate pathway, such as teamwork, task management, time management, problem solving, couching, etc. For educators, especially universities and colleges are encouraged to be the link between students and industries, provide more qualified campaigns and programs for students to approach enterprises such as company field trips, internship program, university ambassador program, competitions and workshops by enterprises. A momentous problem in career preparation is the inconsistency between workforce training by schools and demand of enterprises. It is obvious that if the enterprises recruited labor force from universities to train for them, it will benefit both. This requires enterprises to forecast their demand in human resources in quantity and quality for the future and provide the information to universities and vocational schools. However, it can challenge many enterprises in Vietnam as they are lacking the human resources development planning. Thus, it is suggested that both universities and enterprises should collaborate to achieve the mutual goals. Yet importantly, the purpose of university education is still teaching students the method and skills so that they can quickly learn and adapt in the dynamic world, to train students to be useful citizens devoting to society as a whole.

In short, to succeed in the career path, it depends greatly on the students themselves. The more students involve in academic experiences and gain impressive achievements, the more they are prepared for future career. Furthermore, it is better for students to not only study theories hard but also do research, experiments, join extra curriculum activities, and try some jobs during study program. In these activities, students can recognize their capability and get 
more practical experiences. Therefore, the responsibility of educators is to stimulate and guide students from the very young age. Besides, the useful encouragement from parents and siblings is quite important so that students can identify and develop their natural talents.

There are limitations in this study. Due to time and ability constraint, the sample size is relatively small with no examination of separated gender and only focus on a group of economic and business management students.
This sample, therefore, cannot represent for the whole population of Vietnamese students. There are some factors that can also influence career preparation and willingness to work overseas and are not mentioned in this study. For this reason, some factors such as family support, political environment, safety, resistance to change, etc. should be included in the future research models. More studies can be conducted in the following years to observe the obvious power that AEC can generate a dynamic labor market

\section{References}

Arthur, M. B., \& Rousseau, D. M. (1996). The boundaryless career. Oxford University Press.

Arthur, M. B., \& Rousseau, D. M. (2001). The boundaryless career: A new employment principle for a new organizational era. Oxford University Press.

Bagozzi, R. P., \& Yi, Y. (1988). On the evaluation of structural equation models. Journal of the academy of marketing science, 16(1), 74-94.

Creed, P., Prideaux, L. A., \& Patton, W. (2005). Antecedents and consequences of career decisional states in adolescence. Journal of Vocational Behavior, 67(3), 397-412.

Duffy, R. D., \& Dik, B. J. (2009). Beyond the self: External influences in the career development process. The career development quarterly, 58(1), 29-43.

Erikson, E. H. (1968). Youth and crisis. WW Norton \& Company, New York-London, 17.

Feldman, D. C. (2002).Work careers: A developmental perspective. San Francisco, CA: Jossey-Bass.

Feller,R.(1996).The changing workplace: Why it challenges schools. Vocational Education Journal, 71(4), 24-27.

Fisher, T. A., \& Stafford, M. E. (1999). Reliability and validity of the Career Influence Inventory: A pilot study. Journal of Career Assessment, 7(2), 187-202.

Fornell, C., \& Larcker, D. F. (1981). Evaluating structural equation models with unobservable variables and measurement error. Journal of marketing research, 39-50.

Forster, N. (1992). International managers and mobile families: the professional and personal dynamics of transnational career pathing and job mobility in the 1990s. International Journal of Human Resource Management, 3(3), 605-624.

Fraser, I. (1991) 'Man-Traps for Expatriates', The Observer, 29 December.

Fredricks, J. A., Blumenfeld, P. C., \& Paris, A. H. (2004). School engagement: Potential of the concept, state of the evidence. Review of educational research, 74(1), 59-109.

Granrose, C. S., \& Portwood, J. D. (1987). Matching individual career plans and organizational career management. Academy of management Journal, 30(4), 699-720.

Hair, J. F., Sarstedt, M., Ringle, C. M., \& Mena, J. A. (2012). An assessment of the use of partial least squares structural equation modeling in marketing research. Journal of the academy of marketing science, 40(3), 414-433.

Hansen, L. S. (1997). Integrative life planning: Critical tasks for career development and changing life patterns. San Francisco: Jossey-Bass. 
Hellenga, K., Aber, M. S., \& Rhodes, J. E. (2002). African American adolescent mothers' vocational aspirationexpectation gap: Individual, social and environmental influences. Psychology of Women Quarterly, 26(3), 200-212.

Holland, J. L. (1997). Making vocational choices: A theory of vocational personalities and work environments . Psychological Assessment Resources.

Hughey, K. F., \& Hughey, J. K. (1999). Preparing students for the future: Making career development a priority. Journal of Career Development, 25(3), 203-216.

Jepsen, D. A., \& Dickson, G. L. (2003). Continuity in Life-Span Career Development: Career Exploration as a Precursor to Career Establishment. The Career Development Quarterly, 51(3), 217-233.

Johnson, M. K., \& Mortimer, J. T. (2002). Career choice and development from a sociological perspective. Career choice and development, 4, 37-81.

Lent, R. W., Brown, S. D., \& Hackett, G. (1994). Toward a unifying social cognitive theory of career and academic interest, choice, and performance. Journal of vocational behavior, 45(1), 79-122.

Leung, S. A. (2008). The big five career theories. In International handbook of career guidance (115-132). Springer Netherlands.

Loutfallah, S. W. (2014). An Exploration of the Relationship Between Socio-Economic Factors and Career Readiness in University Students in Lebanon (Doctoral dissertation, University of East London).

Marock, C. (2008). Grappling with youth employability in South Africa. Unpublished paper, Human Sciences Research Council, Pretoria.

Mendel,R. (1994). The American school-to-career movement: A background paper for policymaker sand foundation officers. Washington, DC: American Youth Policy Forum

Miles, R. E., \& Snow, C. C. (1996). Twenty-first century careers. The boundaryless career: A new employment principle for a new organizational era, 97-115.

Ministry of Labor, War Invalids and Social Affairs (1). (2015, July 20). Công bố Bản tin cập nhật thị trường lao động số 5, Quý I/2015. Retrieved February 18, 2015, from

http://www.molisa.gov.vn/vi/Pages/chitiettin.aspx?IDNews=23122

Ministry of Labor, War Invalids and Social Affairs (2). (2015, November 28). Tin Tức | Dự báo nguồn Nhân lực. Retrieved February 18, 2016, from http://www.dubaonhanluchcmc.gov.vn/tin-tuc/5605.thao-luan-sinh-vien-vaky-nang-mem.html

Mortimer, J. T., Zimmer-Gembeck, M. J., Holmes, M., \& Shanahan, M. J. (2002). The process of occupational decision making: Patterns during the transition to adulthood. Journal of Vocational Behavior, 61(3), 439-465.

Newburry, W., Belkin, L. Y., \& Ansari, P. (2008). Perceived career opportunities from globalization: globalization capabilities and attitudes towards women in Iran and the US. Journal of International Business Studies, 39(5), 814-832.

Noe, R. A., \& Barber, A. E. (1993). Willingness to accept mobility opportunities: Destination makes a difference. Journal of Organizational Behavior, 14(2), 159-175.

Nota, L., Ferrari, L., Solberg, V. S. H., \& Soresi, S. (2007). Career search self-efficacy, family support, and career indecision with Italian youth. Journal of Career Assessment, 15(2), 181-193.

Ottaviano, G. I., \& Thisse, J. F. (2002). Integration, agglomeration and the political economics of factor mobility. Journal of Public Economics, 83(3), 429-456.

Parsons, F. (1909). Choosing a vocation. Houghton Mifflin.

Peng, D. X., \& Lai, F. (2012). Using partial least squares in operations management research: A practical guideline and summary of past research. Journal of Operations Management, 30(6), 467-480.

Peng, D. X., \& Lai, F. (2012). Using partial least squares in operations management research: A practical guideline and summary of past research. Journal of Operations Management, 30(6), 467-480. 
Perry, J. C., Liu, X., \& Pabian, Y. (2010). School engagement as a mediator of academic performance among urban youth: The role of career preparation, parental career support, and teacher support. The Counseling Psychologist, 38(2), 269-295.

Roberts, K. (1968). The entry into employment: an approach towards a general theory1. The Sociological Review, 16(2), 165-182.

Savickas, M. L. (2002). Career construction. Career choice and development, 149-205.

Secretary's Commission on Achieving Necessary Skills. (1991). What work requires of schools: A SCANS report for America 2000. Washington, DC: U.S. Department of Labor.

Skorikov, V. (2007). Continuity in adolescent career preparation and its effects on adjustment. Journal of Vocational Behavior, 70, 8-2.

Stambulova, N. B., \& Alfermann, D. (2009). Putting culture into context: Cultural and cross-cultural perspectives in career development and transition research and practice. International journal of sport and exercise psychology, 7(3), 292-308.

Steenkamp, J. B. E., \& Van Trijp, H. C. (1991). The use of LISREL in validating marketing constructs. International Journal of Research in marketing, 8(4), 283-299.

Super, D. E. (1957). The psychology of careers (Vol. 195). New York: Harper \& Row.

Super, D. E. (1990). A life-span, life-space approach to career development. In D. Brown \& L. Brooks (Eds.), Career choice and development: Applying contemporary theories to practice (2nd ed., pp. 197-262). San Francisco, CA: Jossey-Bass.

Tams, S., \& Arthur, M. B. (2007). Studying careers across cultures: Distinguishing international, cross-cultural, and globalization perspectives. Career Development International, 12(1), 86-98.

Thom, G. (1992). The single European market and labour mobility. Industrial Relations Journal, 23(1), 14-25.

Tremblay, K. (2002). Student mobility between and towards OECD countries: a comparative analysis. International mobility of the highly skilled, 39-67.

Trice, A. G., \& Yoo, J. E. (2007). International graduate students' perceptions of their academic experience. Journal of Research in International Education, 6(1), 41-66.

Trinh, T. V., \& Pham, C. H. (2013). Báo động, 70\% sinh viên năm cuối không biết làm gì sau khi tốt nghiệp. Retrieved February 20, 2016, from http://www.sinma.edu.vn/bao-dong-70-sinh-vien-nam-cuoi-khong-bietlam-gi-sau-khi-tot-nghiep/

Vondracek, F. W., \& Skorikov, V. B. (1997). Leisure, school, and work activity preferences and their role in vocational identity development. The Career Development Quarterly, 45(4), 322-340.

Zimmermann, K. F. (2005). European labour mobility: challenges and potentials. De Economist, 153(4), $425-450$.

Zunker, V. G. (2006).Career counseling: A holistic approach (7th ed.). London, England: Thomson Learning. 